\title{
Active instruments: on the use of university rankings in developing national systems of higher education
}

DOI:

10.1080/23322969.2016.1236351

\section{Document Version}

Accepted author manuscript

Link to publication record in Manchester Research Explorer

\section{Citation for published version (APA):}

Lim, M. A., \& Williams Oerberg, J. (2017). Active instruments: on the use of university rankings in developing national systems of higher education. Policy Reviews in Higher Education, 91-108.

https://doi.org/10.1080/23322969.2016.1236351

\section{Published in:}

Policy Reviews in Higher Education

\section{Citing this paper}

Please note that where the full-text provided on Manchester Research Explorer is the Author Accepted Manuscript or Proof version this may differ from the final Published version. If citing, it is advised that you check and use the publisher's definitive version.

\section{General rights}

Copyright and moral rights for the publications made accessible in the Research Explorer are retained by the authors and/or other copyright owners and it is a condition of accessing publications that users recognise and abide by the legal requirements associated with these rights.

\section{Takedown policy}

If you believe that this document breaches copyright please refer to the University of Manchester's Takedown Procedures [http://man.ac.uk/04Y6Bo] or contact uml.scholarlycommunications@manchester.ac.uk providing relevant details, so we can investigate your claim.

\section{OPEN ACCESS}


Article Title:

Active Instruments: On the Use of University Rankings in Developing National Systems of Higher Education

Miguel Antonio Lim ${ }^{1}$ and Jakob Williams Oerberg²

1,2 Department of Education / Danish School of Education

Aarhus University, Tuborgvej 164, 2400, Copenhagen, Denmark

mili@edu.au.dk

jwo@edu.au.dk

Authors in alphabetical order. Please address correspondence to both.

Forthcoming in Policy Reviews in Higher Education

Acknowledgements:

This work was supported by the European Commission FP7 People programme: Marie Curie Initial Training Network UNIKE (Universities in the Knowledge Economy) under Grant Agreement number 317452, the Aarhus University Research Foundation, and the COWIfonden. 


\begin{abstract}
Global university rankings set into motion policy responses that highlight and question our understanding of how policies coordinate policy communities. Rankings are often treated merely as accelerators of reform processes and are not explored sufficiently as diverse organizations consisting of different actors and practices. Their role ought not to be so easily generalized; we suggest instead to study encounters between rankers and national policy contexts as occasions of potential tension. Rankings do not just accelerate existing national policy directions - they can change the policy processes themselves. We draw on two multi-year field studies of India and Denmark to investigate how national reforms and developments within the ranking industry interact in often surprising ways. Rankings do not always do what policy makers expect. We (1) highlight the activity of rankers in these two countries, (2) show the dynamic nature of policy processes, and (3) consider the search for policy reference points among the different actors. We present rankers in motion, policies in motion, and finally the complex nature of the ranking device that needs to be both a relevant and malleable policy instrument but also a fixed and legitimate standard. We extend existing arguments about the role of rankings in policy making by showing concretely how rankings are employed in and shape countries' quests for positioning in the global knowledge economy. Rankings demand new explorations of their production and open up a space for new understandings of the links between policy assemblages and wider processes of transformation.
\end{abstract}

Keywords: university rankings, policy assemblages, policy instruments, policy coordination, World Class Universities, Denmark, India 


\section{Active Instruments: On the Use of University Rankings in Developing National Systems of Higher Education}

\section{Introduction}

Higher education systems across the world have been the object of intense reforms in the past two decades. Often characterized by marketization and the rollout of new public management these reform processes have often been summed up under the headline of modernization and globalization or in other interpretations as 'neoliberal reform'. They have been pursued to position countries and their higher education systems in what is perceived as a race to win or survive in the 'global knowledge economy' (Jessop, 2000; Wright, 2012; Wright and Oerberg, 2016). International benchmarking and the development of global university rankings have been described as a driver in these processes, deepening what Shore and Wright (1999) have termed 'audit cultures' and shifts in higher education governance, furthering the commodification of education and research and calling forth market oriented student identities (Naidoo \& Jamieson, 2005; Naidoo \& Williams, 2015), and standardizing the plurality of higher education institutions according to their criteria for world class excellence (Kehm, 2014; Deem et al., 2008; Hazelkorn, 2011).

Rankings often play the role of accelerators in arguments put forward in critical studies of higher education reform. Having already theoretically been established as drivers of neoliberalism in higher education (Hazelkorn, 2011, 13-15) they are often added as contextual elements in analyses of commodification, increased international competition, and coordination (e.g. Naidoo and Williams, 2015, 218; Naidoo et al., 2011, 1153). Rankings often serve in critical studies of higher education transformations to sharpen the interpretation of the policy developments under scrutiny. In policy reviews, even though there is often a habitual flagging of skepticism about their accuracy and relevance, rankings are often employed as unexamined indicators that do not seem, in themselves, to be in need of deep investigation. In this way, rankings can be seen as a way to show the 'progress' of a set of national or regional policies (Mahbubani \& Chye, 2015). Often the result is that these studies arrive at conclusions that are more or less aligned with the current political aims of higher education reform in some countries. 


\section{The 'World Class Universities' contest: a fertile Space for Rankings}

In this article we consider two encounters at a national level between rankings and the concept of the 'World Class University' (WCU), an idea popularized on a global scale by Jamil Salmi and the World Bank's Tertiary Education Program (Salmi, 2009). The juncture between policy makers and the idea of the WCU creates a space for ranking agencies in the education policy process. The idea of the WCU is central in shaping national understandings of what 'top' universities should do and the concept both relies on and shapes the methods that different rankers use. The term traces part of its relevance to the Chinese 'policy 211' and 'policy 985' of the 1990s (Ngok and Guo, 2008), but was only thoroughly institutionalized by Salmi's 2009 book, the Challenge of Establishing World Class Universities, published by the World Bank, which suggested a special role for such central national institutions in economic development.

Denmark and India present two different kinds of engagement with ranking organizations as well as with the concept of WCUs. Quite clearly there are contextual differences - the former is a small, rich country, with a well-developed university sector. The second system is a very large country with a large university system and a highly uneven distribution of quality. Both countries have some notable universities, but both Danish and Indian higher education institutions largely remain outside the very top levels of global rankings. This is sensitive for India as its economic and demographic size and global ambitions suggest that it should have a better representation in this respect. For Denmark it is seen as problematic that its lead position in terms of higher education investment and research productivity does not translate into top ranked institutions. Both countries, however, have decided to engage with the goal of producing world class universities and have used rankings in their strategic discussions regarding the reform of their higher education sectors.

\section{Rankings as agents in their own right}

Our study considers the differences between rankings as well as their ability to change as an indispensable aspect for studying national initiatives around WCU reform. The major 
international university rankings have developed their ranking formats and platforms in a variety of ways. These differences reflect the respective business and organizational contexts of the rankers. Three rankings currently figure most visibly in the international higher education debate. These are the Academic Ranking of World Universities (ARWU) or the Shanghai ranking, the Times Higher Education World University Rankings (THE) and the QS Rankings (QS). The latter two started out as a single set of rankings but split and published separate rankings from 2010.

The varying orientation of rankers means that each can have a different 'feel'. The ARWU rankings are largely oriented around the use of 'objective' indicators, i.e. it does not rely on survey data, and is coordinated largely in the setting of an academic department of Shanghai Jiao Tong University. The THE rankings are made in the context of a media organization which is undergoing an important change as it invests more heavily in its data gathering and processing ability. Finally the QS rankings are made in the context of a consulting firm - it is more business oriented. While there are many linkages within the ranking community the three rankers are oriented towards slightly different audiences. The THE claims that it is oriented towards senior academics and sector 'thought leaders' (P. Baty, personal communication, August 7, 2014). The QS rankings are more oriented towards international students. The ARWU's rankers do not claim to have a particular audience in mind when they develop their rankings although acknowledge that they were developed in the context of the Chinese initiative to build WCUs.

A number of university based ranking initiatives, such as the Leiden rankings which are based on the bibliometric work done at Leiden university have sought to challenge the dominance of the three major global rankers, just as the European Commission funded U-Multirank is projecting itself as an alternative. These initiatives have had some impact, but without strong media partners and readily intelligible top-university lists they act as correctives to rather than substitutions for the big three in international higher education policy debates.

\section{The argument}

We argue that the supporting or coordinating role often assumed for ranking in higher education policy studies is in need of elaboration. The World Class University or other policy concepts 
promoting the role of universities in asserting nations or regions in the global knowledge economy makes global rankings attractive assessment instruments and reform referents. However, the rankings produced by the different rankers are dynamic; they respond to audience needs, reactions from various academic advisers, and to commercial and operational pressures on the ranking makers. Rankings also change in response to new data gathering techniques and to other developments in their industrial partners such as the bibliometric providers. As a result they can be unstable tools for policy development and can, as we shall see, sit uncomfortably decoupled from nations' wider strategies for higher education reform. Instead of subsuming rankings to the role of a driver in wider national or global reform developments, we suggest the need to study the varied encounters between national policy agendas and global rankings and the policy assemblages they articulate.

We draw on Collier and Ong's work on 'global assemblages' (2005) in employing the term 'policy assemblage' to conceptualize the mix of policies, steering technologies, discursive elements, human and social agents, among others, that constitute the spaces of reform in higher education in which rankings are employed. Building on this, we characterize and discuss this 'space' as a global policy assemblage and show, precisely through the image of an assemblage of parts, that the differences among the rankers - as active rather than passive parts - lead to some interesting configurations in how national policy makers negotiate their goals and actions to create WCUs.

In the article we show and examine two kinds of engagement between national policy systems and rankers. Denmark, the first, is a case of engagement with rankings without communication with rankers, while in India, the second case, policymakers engaged and communicated intensely with rankings and rankers. Denmark and India both incorporated the work of international rankings into the development of national systems of evaluation but India took a step further and invited key actors from one of the ranking agencies to participate in a policy process around higher education reform.

We draw on two multi-year field studies of India and Denmark, experience from policy making in the Danish context, as well as a year-long period of observation at the Times Higher Education Rankings to investigate how these national policy processes and developments within the ranking business interacted in often surprising ways. One of the authors developed a familiarity with the 
policy making process while working at the Danish Ministry of Higher Education. Fieldwork, interviews, and document analysis, were carried out in Denmark, India, and in London.

After presenting these cases, we develop a tripartite discussion that highlights the activity of rankers, the dynamic nature of policy processes, and the constant search for some reference points among the different actors. We present rankers in motion, policies in motion, and the complex nature of the ranking that offer both a relevant and thus malleable policy instrument but also a fixed and thus legitimate point of reference.

\section{Denmark: Coming to Terms with the Instability of Ranking Instruments}

Global rankings of universities entered the Danish debate on higher education in the form of critique. As the first Anders Fogh Rasmussen government embarked on a wholesale reform of the Danish university system in 2003, critics pointed to ranking both to showcase the difference in conditions between top ranked American universities and the ones produced by the Danish reform, and in some cases by questioning the need for reform by pointing to the high rank of University of Copenhagen in a European context (Kyng, 2005; Berlingske Tidende, 2004). The government responded by questioning the relevance of rankings for policy debates, especially considering their apparently flawed methodologies. Meanwhile, while metaphors from competitive sports increasingly found place in statements from the Ministry of Science, Technology and Innovation, the travel schedule of Danish ministers and top policy makers often included universities like Stanford and Yale, which were consistently ranked at the top of the global rankings.

When in 2006, Prime Minister Anders Fogh Rasmussen announced that Denmark should dare to dream of 'world class universities' critics were quick to point to the universities topping rankings such as Harvard, Yale, Oxford and Cambridge and suggest that Danish universities were unlikely to be able to compete on that level (Rasmussen, 2006). Instead, they said, Denmark should embark on a strategy to develop niche universities based on specific research areas where Danish universities had an edge (ibid). The Danish strategy for globalization from 2006 had the creation of WCUs as a separate policy aim and stated that Danish universities should measure up to the best in the world so that they could better sustain the development of Danish society in the 
context of globalization (Danish Government, 2006). From this aim followed a range of policy measures such as performance based basic grants, mergers between universities and government research institutes and a stronger implementation of 'international standards' in education programs (ibid, 22-23). However, rankings were not accepted as the parameter against which to measure the successful performance of the universities.

Instead rankings entered policy making in Denmark in relation to instruments in the periphery of higher education policy making. A scheme to enhance the mobility of Danish students promised financial support to students studying at good foreign universities and as Danish migration policy shifted towards a focus on high skill labor, foreign workers were rewarded for attendance at highly ranked universities in the 'point system' for acquiring a 'green card' work permit (Hazelkorn, 2013). In both cases the top 100 universities in the global rankings - the (then) THEQS and ARWU - was the accepted yardstick.

The Government's reluctance to make rankings a basis for policy making continued into 2009 when universities went through an international evaluation focused especially on the effect of institutional mergers (Ministry of Science, Technology and Innovation, 2009a). The Universities' performance in rankings did, in the end, become a part of the very large background material for the policy, however with the disclaimer that performance of the institutions would exhibit a lot of variation based on the ranking methodologies. There was a limited premise that a bettered overall ranking of the Danish universities is indicative of a greater international impact of research' (Danish University and Property Agency, 2009, 5). In 2009 the Ministry of Science also published an overall annual review of Danish research performance for the first time and, although rankings (or even specific institutions) were not mentioned in the introduction to the report penned by the Minister of Science, Technology and Innovation, Helge Sander, the report itself dedicated seven (out of 84) pages to examining rankings and their methodologies. It focused on Denmark's performance as well as judged the country's ability to produce top-100 universities in all the rankings referenced in the report, i.e. the ARWU Rankings, Leiden Rankings, and the (then) THE-QS rankings (Ministry of Science, Technology and Innovation, 2009b, 36-42).

When a new prime minister Lars Løkke Rasmussen took office in 2009 the government position on rankings shifted radically. Rankings came to prominence when he declared that Denmark was to have one university in the European top ten of the THE-QS rankings by 2020 (Tang, 2009). 
The government also maintained that no Danish university was to fall back in their international ranking positions (Prime Minister's Office, 2010). At the best ranked Danish universities the immediate response was to ask for more money to deliver on the demand. In the Ministry of Science, Technology and Innovation on the other hand the target had a lukewarm reception. Work to understand the underlying ranking methodologies was initiated while outside consultants' proposals for quick fixes for ranking improvements were turned down. Increasing calls in the European policy space for stronger differentiation within national university sectors (cf. van Vught, 2009) were also given only limited attention.

Finally, developments in the ranking industry complicated the Danish policy setting even further. In the 2010 the Times Higher Education and QS rankings split and decided to produce their own separate ranking instruments. Because of changes in the methodology of the now separate THE rankings Danish universities plunged in the 2010 THE Ranking. Their positions in the QS rankings which held to the previous methodology were more stable.

The decision as to which of the two rankings resulting from the split in the ranking industry to use as an index became a policy headache at the Ministry of Science, Technology and Innovation and so did the overall role of rankings in policymaking. Denmark sought to enlist its universities for the EU Multi-Rank project seeking to establish a strong Nordic presence in the new ranking (or rating) format (Ministry for Children, Education and Gender Equality, 2010). Some Danish universities argued that the Leiden rankings would be a better choice for assessments of international rank, due to its supposedly higher degree of scientific validity (Frandsen and Lyall, 2012). Meanwhile, while announced repeatedly, a direct tie-up of ranking and performance assessments of universities remained an undeveloped clause in the government's policy program.

Unable to use ranking as a consistent indicator to evaluate the aim of establishing world class universities in Denmark, but working towards a policy aim defined in terms of ranking, the government was looking for other ways of making rankings count. In its Growth Forum (Vækstforum), a high profile policy deliberation process in 2010 and 2011, global rankings became the most important international indicators of university performance (Danish Government, 2011). In the background report for the policy deliberation, a diverse set of high performing European universities were identified as benchmarks largely by assessing these universities' performance across the major rankings. This benchmark set was subsequently used to identify 
differences and similarities to the major Danish universities and served as the basis for necessary changes for Denmark's universities to enter the top of the European league. Even still, reflecting the inertia of the Danish policy consensus the report put emphasis on the overall increased performance of the university sector, while suggesting a slight turn towards a differentiation of the Danish university sector focusing more resources on the strongest institutions.

The shift in the ranking business composition and the subsequent shift in methodology of the ranking of choice for government had, on the one hand, led to the existence of a policy aim formulated in a way that rendered it unachievable. What was once a clear target became two different sets of targets because of a rift among the providers of the indicator that Denmark was looking to. On the other hand the mention of rankings in government overall policy aims forged a benchmarking methodology based on rankings and thereby pushed rankings to the center of Denmark's understanding of its international competitiveness. Building on this methodology rankings were integrated into the general mold of Danish policy rather than providing a disruptive outside policy target. Moving the policy agenda forward in a slow 'double shuffle' towards differentiation and competition (cf. Wright and Oerberg, 2011) ranking helped define an ambition to differentiate the university sector further, acting as its supporting leg, the focus on overall sector achievement, guaranteed a sustained 'equal playing field' in the sector. The government's ambition to reach the European top measured through rankings was upheld as an ambition while the analysis of targeted benchmarks resulting from it was but a slide tilt of the hitherto policy framework of relatively uniform incentives for the quite diverse eight Danish universities.

When the Danish government changed once again in 2011, positioning in the rankings as a policy aim disappeared from the government agenda. However, ranking as a serious factor in the definition of the international or global standard remained strong. The idea that university performance quality should be understood in an international context had also been cemented. When the University of Copenhagen in early 2016 went through a series of cutbacks due to diminishing government support, its autonomous university paper called on Phil Baty of the THE Rankings to provide the critical interpretation of the consequences to the global standing of the Danish flagship university (Richter, 2016). 


\section{India: Giving Voice to Rankers in the Policy Debate}

India has also considered how to engage with global rankings because of its own ambition to create WCUs. In India, as in Denmark, this led to the mainstreaming of global rankings into the policy debate. On the recommendation of the National Knowledge Commission, India in 2007 announced that it would build $30 \mathrm{WCUs}$ (IANS, 2007). The recommendation referenced international rankings and claimed that India, apart from the IITs, had problems reaching a globally competitive level. The 2011 Kabodkar report (Ministry of Human Resource Development, 2011) continued this line of argument with a focus on the IITs as the basis for building WCUs and suggested better reporting and benchmarking of IITs as concrete policy measures to achieve this.

In India rankings were initially an instrument for the critical assessment of government policy by the opposition. Indian parliamentarians have continuously questioned the performance of India's universities globally since the first ARWU ranking in 2003 (see Rajya Sabha, 2005). Parliamentary debate records show the answer from shifting government ministers to questions in parliament about this lackluster performance has as late as 2012 been that rankings are not good tools for quality assessment especially of Indian universities and that the government was already working hard to further the level of university quality (see Rajya Sabha, 2012). This line shifted as the use of ranking performance became instrumental for framing the need for WCUs and the roll-out of instruments to promote them.

Whereas government officials would earlier deflect media or parliament criticism over Indian institutions' performance in rankings, in more recent years the government has instead presented analyses presenting ranking performance while not fully endorsing them in setting policy aims (see Rajya Sabha, 2013). This placed the IITs and the most prominent central universities in a lonely position to defend their perceived poor performance in global rankings. They responded by pointing to methodological challenges on the part of the rankings in how they considered the Indian context. In a harsh critique the director of the QS ranking, Ben Sowter, was at one point accused in a heated television debate of demanding payments for the proper evaluation of Indian institutions (NDTV, 2013). This happened shortly after Phil Baty, editor of the THE Rankings, had been drawn to publicly refute reports in the Indian media that THE was prepared to modify their ranking instruments to better fit Indian institutional constraints and take account of India's

disadvantages in the THE's own methodology. These included, among others, the high degree of 
affirmative action to allot study places to underserved populations as well as legal constraints to developing a stronger international presence of students and faculty at Indian public universities. The Times of India reported that the THE Rankings 'had agreed to draw up an India specific indicator that would help global education stakeholders and international students to judge Indian educational institutions' (Times of India,2014) and that the Indian government supported the use of the Times Higher Education as the preferred and 'principal yardstick' for India's universities. Baty was quick to respond that the THE would not change their rankings:

"We are delighted to be working closely with the Indian government to help make sure that our rich and trusted data can be used to help India's higher education development, and drive to improve quality. We have no plans to alter the overall World University Rankings, and we would never change this international gold standard without extensive global consultation. But we are very happy to explore different balances of our metrics, and potentially new metrics, to help India better understand and monitor its universities performance against our trusted global benchmarks, but also reflecting local developmental priorities and concerns." (Baty, 2013)

The THE did eventually introduce an India oriented instrument in the form of the India-only Reputation Ranking that only ranked Indian institutions according to their performance in the THE's reputational survey. This ranking placed the Indian Institute of Science-Bangalore at the top of the table together with the IITs and thereby addressed a previous critique against THE's global ranking which had showed Panjab University as the top Indian university. Panjab's performance, while respected in the Indian context, was a surprising result for the Indian community. Its place in the global ranking was largely due to an extraordinary bibliometric performance in that period. The reputation ranking cemented the 'common sense' in India regarding which institutions were best. But it also benchmarked Indian institutions against worldwide peers. The reputation survey placed IISc Bangalore 130th in the world and IIT Bombay at 192 thereby placing Indian institutions, finally, within the top 200 of a global ranking.

In contrast to the Danish case, officials from the major global ranking makers played an active and visible role in the Indian media debate as well as in the policy community. In May 2013 the 
Indian Planning Commission and the Ministry of Human Resource Development (MHRD) organized a 'National Policy Dialogue on university rankings, research evaluation, and research funding' in collaboration with the British Council. The dialogue involved Phil Baty of THE. At the meeting Baty spoke to more than 130 participants described by British Council as 'key decision makers' at top Indian institutions (British Council, 2013). India's Minister of State for Human Resource Development, Shashi Tharoor, both hosted and keynoted the event.

The British Council (2013) recorded that while there was a divided opinion on the relevance and methodology of the rankings as well as around the linking of research funding to performance policy makers pushed for universities to engage with rankings. Higher Education Secretary and a member of the Kakodbar commission on IITs, Ashok Thakur, subsequently acknowledged the need to be strategic about the sector: "We must play the same game the rest of the world is playing. We need not be shy about it." (Thakur, 2013) He further confirmed that the MHRD had instructed Indian institutions such as the Indian Institutes of Technology (IITs ), the National Institutes of Technology (NUTs) and the central universities to "appoint a nodal person to coordinate with the Times Higher Education" (Thakur, 2014).

At subsequent meetings in the IIT council, the body that coordinates policy initiatives across the IIT system, rankings and the IITs' response to them came into focus (IIT Council, 2013). The IITs formed a steering group to create a common ranking strategy. In parallel, the government rolled out an IIT peer review process where each of the IITs was evaluated by a panel of experts. The proposed format for the review was highly focused on publication outputs and other quantitative indicators for research and teaching. At many departments in the system this data had to be compiled afresh. This process created a more complete picture of performance data across the institutions and notably a stronger capability for engaging ranking agencies. To illustrate, the final peer review of IIT Delhi has a section on recommendations related to rankings, including a recommendation to work closely with a particular ranking service to ensure more targeted performance especially in research and to identify relevant peer institutions to learn from and benchmark against (Indian Institute of Technology Delhi, 2014, 7-8).

Meanwhile, the Indian Planning Commission and the Ministry for Human Resource Development developed and implemented a two pronged approach when it came to rankings. Indian top institutions were expected to engage more actively with global ranking frameworks while an 
internal Indian ranking that took into account other aims for the universities apart from those accounted for in global league tables were to be developed on the government's own initiative ${ }^{1}$. Reflecting this, Phil Baty of the THE said he saw the Indian government's ambition in the ranking debate as much as an attempt to start a serious debate on research performance and assessments internally in India as an effort to position Indian universities globally (P. Baty, personal communication, January 31, 2016).

The THE aims to maintain its engagement with India's university sector and policy makers. In late 2015 the THE held its BRICS and Emerging Universities Summit in New Delhi, hosted by the O.P. Jindal Global University. Preceding this conference was a meeting at the Indian Presidential residence with the heads of 114 'central' institutions as well as the Indian President. The President, Pranab Mukherjee, conveyed his sense of India's opportunity to increase innovation as well as competitiveness: 'if we provide enough funds to the top 10 to 15 institutions for the next four to five years, these institutions will certainly storm into the top 100 of global academic rankings within the next few years' (Mukherjee [2015], in Altbach, 2016).

Despite this engagement, publications of rankings in India are often followed by public outcry both against rankings and against the perceived lack of quality in the Indian higher education sector, especially in the IIT-system (NDTV, 2013). This attention allows rankers, universities, government and even the opposition to deepen debates over performance assessments in the sector. Rankers have not been silent or immobile in this debate. As we have seen, they have both defended themselves from criticism as well as tried to maintain a balance of engaged participation with the sector. They have in the process produced new instruments relevant for India. The production of the Asian or BRICS-specific and 'young university' rankings by the global ranking agencies has further sustained the perceived relevance of ranking in the Indian debate and the debate in turn has served as the context for both the recent IIT review and the development of an India specific ranking by the government.

The exposure to rankings strengthens the pressure on Indian universities to produce and deliver data on their performance either to government or ranking agencies. There has been an intense round of communication between rankers and government as well as university officials to clarify

\footnotetext{
1 The Indian Ministry of Human Ressource Development have set up the National Institutional Ranking Framework for this purpose: https://www.nirfindia.org/NIRFIndia/About
} 
the issues related to Indian ranking performance. This heightened attention to ranking in the Indian context has strengthened government's ability to demand more consistent data from IITs and universities alike.

\section{Rankers in Motion: Rankings as Active 'Instruments'}

The production of international rankings is fundamentally focused on the listing of universities globally according to a particular ranking's methodology for assessment of what a good university is. Some rankings seek to establish 'objective' yardsticks for comparison between institutions in different higher education systems and traditions. Others include 'subjective', i.e. survey based data, which aims to capture the value of a university's reputation. In both cases the methodological construction of a ranking favors certain types and nationalities of institutions. Each ranking has its own history and particular vision of university excellence as well as a need to advance that notion, if not for anything else, in order to create a market for its services.

All three major global rankings have developed a diverse set of sub-lists that rank universities according to, among others, geography, age, or academic discipline. The rankings' appeal hinges on their ability to maintain an international character and standard (e.g. the global top university list) as detached from the national policy processes their rankings are used in while securing the relevance of their assessments through sub-rankings that match local interests and needs. Rankings must balance trust and intelligibility in the processes and contexts they are read or put to use in. Rankings are thus in a constant process of calibration and improvement to negotiate this balance and some rankings are cautiously managing their media presence as well as the perception of their activities among their diverse audiences of politicians, university officials, students, and the mass media.

The 'logics of ranking' and the wider context of knowledge competition need to be accepted, and actively engaged with, in a national context for rankings to have an impact in national policy making and for rankings to be successful as business ventures. Arguments around whether it is right to compare the perceived top national universities with the universities that are at the top of global rankings have become commonplace. As we have seen in the case of Denmark and especially in India they have become central to political struggles. The desire to compare and 
achieve a working relationship with the 'absolute elite' is more and more a matter of government policy. Elite institutions in the education clusters in greater San Francisco and Boston in the United States often receive parliamentarians searching for 'best practices'. Similarly, former Danish higher education and research minister, Esben Lunde Larsen, visited Cambridge and Oxford in England in early 2016 in search of these lessons. Indian politicians' repeated push for allowing foreign providers of higher education to operate in India is in parallel to this. It is mostly brought forward with the expectation that universities such as Harvard or New York University will set up shop in their country and drive their system's quality upwards (Tharoor, 2015).

The operationalization of the WCU concept on a global scale by Salmi, then in his role as coordinator of the World Bank's Tertiary Education Program, pointed to ranking in its search for defining examples of WCU noting that top ranked universities were drivers of regional and national economies (Salmi, 2009). The circularity of this reference has since been highlighted by the interest taken in rankings by governments, universities, and the media in debates and policy efforts focused on creating WCU while fully equating "World Class" with "top ranked" regardless of the definitions of World Class that are implicitly constructed in the rankings (Deem et al., 2008).

In other countries governments have talked of roughly equivalent goals to establish lighthouse, national universities, or flagship institutions (Douglass, 2016) actualizing a need for international comparison both to identify and understand their ambitions and to evaluate and market their achievements. Interestingly, as in India, sometimes these initiatives serve as a point on which the political opposition derides the government. It is perhaps not surprising that the WCU-concept is contested. The WCU, as Salmi's book suggests, mediates between a space of global excellence and national priorities. It invites debate.

In parallel to the drive for WCUs by governments, ranking agencies aimed to take on a more sophisticated role of defining success in the global higher education sector. In a report from the European Commission (2009) governments and policy makers were still expressing considerable doubt about the impact and need of ranking, although both the negative and positive consequences of rankings in the debate over the overall quality was acknowledged. Meanwhile, the European Commission pushed along with its initiative to devise in U-Multirank a ranking tool more in tune with 'European' priorities. A recent survey by Elken et al. (2016) working with 
the Nordic Institute for Studies in Innovation, Research and Education (NIFU) reached a similar conclusion - there were many apprehensions about rankings at the university level and although they had a 'modest' effect that did not 'challenge the existing identities' (ibid, 1) of Nordic universities, the rankings' presence could not be ignored.

Denmark stood out in the report mentioned above as the only country with an explicit use of ranking in policy schemes (European Commission, 2009). In India and Denmark the government countered questions about rankings throughout the 2000s by raising the issue of the quality of ranking indicators while maintaining they were working to improve higher education standards. Yet by 2009 both India and Denmark had embraced notions about the WCU, and as we have seen, the role of ranking is embedded in both countries' higher education policy debate. In June 2014, the then secretary of higher education in India, Ashok Thakur, stated that it was a prioritized political aim that the best Indian universities should rise in the global rankings (Thakur, 2014) while Denmark incorporated ranking in government targets in 2009.

\section{Policy in Motion: International Rankings and National Policy Developments}

Based on the Indian and Danish cases, we propose a more nuanced understanding of the role of rankings in the policy 'mix'. We argue that the methods of international benchmarking in national reform processes are good entry points in which to study the interface between outside 'experts', such as rankers and other evaluators, and the reform process itself. To begin accounting for this interface however, the reform process must be understood as an at times uncoordinated assembly of actors, instruments, and processes. What we see in the case of rankings is that rankings must be understood as much more than a mere instrument in the process. Rankers are active participants in the mix who can challenge and move positions within the reform assemblage. They act to become relevant, they negotiate rejection, and some of them work their way back into (or are worked into) the policy assemblage when required.

How can we understand this fluid image? We seek neither to overemphasize rankings' importance nor to leave them merely as inert in our analysis. Steiner Khamsi (2014) points out that "global forces" are sometimes locally induced with the purpose of generating reform on domestic developments' (ibid, 155). She further argues, that outside references are made at 
moments of policy contestation, and that we for these reasons must see policy borrowing as always selective and with country specific outcomes. Both the marketing and 'packaging' of 'global policy' or policy referents determines their effectiveness in national systems, she suggests. What we are aiming to insert in this description is the active movement of the referent itself, as it is being incorporated in a new policy context, i.e. the ranking agencies' operations.

Although there has been a recent growth in national schemes to perform better in global university rankings, direct and explicit linkages between ranking and government policies are still relatively few. While researchers assert that rankings are important factors or even drivers of higher education reform (Hazelkorn, 2011), understanding rankings' actual engagement with national policies still needs more of the kind of work we attempt here. Whereas some studies argue that university rankings are among the main drivers in the reforming of systems in direction of neoliberalism and marketization (Kehm 2014; Naidoo et al. 2011), the overt incorporation of rankings in reform processes has been limited, although growing, in both Europe and South Asia. Instead rankings have had loose relationships to government visions, and especially to debates over the concept of 'World Class'.

Typically institutions and governments have embraced rankings in which their universities do well and have downplayed the rankings in which they perform poorly. However, at one point, in both the Danish and Indian cases, rankings were fully embraced by government officials, which set the two countries apart from many counterparts globally. Denmark and India have both had policy debates and initiatives where the figure of the WCU has been prominent in recent years. In both cases international rankings have come to play a decisive role in how this concept have been interpreted and developed in the national policy systems. Likewise, in both cases, developments in the league tables themselves have had widespread consequences for the development of policy processes.

In some cases the developments in the rankings produced were considered favorable to goals set by policy makers. However, in other cases, they were not. In the end there was a certain degree of unpredictability due to processes internal to the ranking industry or the individual ranking device which was outside the influence of the policy makers. Denmark and India are good cases for the study of both ambivalent and direct engagements with rankings in university reform 
processes. And as we have seen, both cases raise doubts about often suggested uniform and hegemonic effects or appropriations of rankings.

The conceptualization of the policy transfer as taking place in a policy assemblage allows first of all for a description of ranking's engagement in the national reform space without its subjugation to the same, as it allows for the inclusive inscription of other processes and developments into the assessment of policy processes involving rankings. Collier and Ong (2005) develop the concept of 'global assemblage' to understand how reform can encompass and be a product of multiple determinations that are not reducible to one logic. They metaphorically draw on computation and argue that just as 'global variables' must be seen as much as defined through their articulation with other variables as through their global character, global trends such as neoliberalism much be understood through the contingency of their articulation with national policy processes, historical forms of governance and political interests.

Global university rankings are not only analytically 'global variables', but actively reproduce and market themselves as such. Rankings' effects and continued relevance depends on how well they articulate with and respond to the national, regional and international policy processes. To understand their interaction with higher education reform, we must begin to see them as variables with 'a mind of their own'.

\section{A difficult search for a fixed point: the Role of a Global Benchmark}

The role of ranking in university reform varies. In the Danish case ranking was used as a means to identify the world class that governments of different hues have aimed to engage with. Tellingly, Danish ministry delegations to the US most often visit 'elite' universities such as Stanford, Harvard and MIT, even while public universities such as the University of Michigan would arguably have been a more fitting role model and benchmark for Danish universities which are comprehensive public institutions. Rankings, like such visits, can even be seen as propping up higher education policies by way of association. In the Danish case referred to in this article, rankings entered as a new prime minister who had hitherto been an ordinary minister in the government had to mark his ambitiousness when taking over the office of his predecessor. In the Indian case, the Indian government in contrast took advantage of a poor ranking in 2012 and 
2013 of its most prestigious institutions to allow pressure for better data gathering and stronger focus on research performance to be built into the policy debate. It had repeatedly disregarded rankings and argued for their limited validity in the Indian context, but with the momentum of the public debate over IITs performance, government gained momentum in its attempt to strengthen 'accountability' of universities and especially the IITs.

In both the Danish and Indian cases the incorporation of rankings in the policy debate ran in parallel with the development of more comprehensive data for the countries' higher education policies. In India the role out of the IIT peer review was highly focused on numerical indicators, while in Denmark, the increased incorporation of rankings in policy making ran in parallel to a new incentive structure that both rewarded and systematized bibliometric research evaluation. Agarwal (2013), an Indian national policy maker and researcher, argues that the pressure from rankings pushes institutions and higher education systems towards better and more transparent data collection. As we have seen in the Indian case, the actualization of rankings in the higher education debate in recent years is utilized to create a greater concern over data across the Indian higher education system and significantly through the development of a national ranking. The technical image of rankings and especially bibliometric analysis which is held to measure the quality and impact of research is a crucial factor in the widespread use and readability of rankings. We suggest that more research is needed on the concrete material objects that are necessary for rankings to function. These include large data sets but also such mundane items as excel tables and assessment forms.

While the ranking organizations are seeking ways to become attractive to local markets, they maintain the 'detached' so-called global standard in their analysis. Ranking makers have increasingly marketed their instruments to developing nations and have accommodated them by creating new rankings that focus only on a smaller subset of the global rankings. Many ranking makers, for example, have regional rankings alongside 'young' universities' rankings, technical universities' rankings, the innovation rankings, and others. Some of these rankings place Indian universities in league tables alongside Asian or BRICS peers. In these, Indian universities' performance comes closer to the Indian public's perception of their standing. This is to say that rankers seek to be both relevant to their local audiences but also 'distant' and objective enough to 
be seen as a reliable standard. The rankers' primary currency is credibility and each develops strategies to legitimate itself to its audiences.

As we have seen in both the Indian and the Danish cases the engagement with rankings for policy makers can lead to surprising or unwelcome outcomes. Continuous modifications to ranking methodologies, data improvements, and other industry developments make the rankings unstable tools for policy development, and while they may play a coordinating role in processes of policy making and policy transfer, it is of a different sort than other processes of coordination taking place within, for instance, the OECD or World Bank, where the interfaces between national and international policy worlds are discernible although ripe with unequal power relations (Wright and Oerberg, 2011). Some researchers have reported that large scale policy making can be set into motion when systems experience 'ranking shocks', as happened to Malaysia in 2006 (Salmi, 2009) and France in 2008 (Enserink, 2007), and to some degree in India in 2012 and 2013. Rankings are coordinating instruments in that they translate national and institutional performance into intelligible although unstable hierarchies. However, the development of rankings is only partially aligned with national and transnational reform agendas. When national policy makers attempt to articulate the 'futures' of their university systems through engaging with rankings, they in essence introduce a measure of unpredictability to the policy process.

\section{Conclusion}

We have traced in some detail how rankers have begun to engage with policy makers and not always along the lines previously foreseen by the national officials. Rankings played a role in Indian government efforts to steer institution building. The Indian government turned to rankings and let a ranking debate take off both in media and the policy community at the point in which rankings seemed to serve its own policy goals of reforming a sector that was seen to be underperforming. This especially entailed the aim to promote World Class University-type parameters for developing the nation's top universities. The government strengthened the push for data collection at the IITs and the centrality of ranking in the debate further allowed the policy momentum for developing a domestic ranking. With relatively few central government 
instruments to direct higher education development, rankings have served India as an important vehicle for coordination. In Denmark rankings were allowed a place central to the policy debate, but the development in the ranking industry and the ranking tables themselves made their role in the policy space unpredictable.

Rankers are turning to developing new regional and national rankings. The THE, which considers senior university managers and thought leaders as their core audience, continues to aim to be part of policy processes. We suggest a need to pay particular attention both to rankers and their instruments - the rankings - by which changes in higher education policy are being framed. Rankings play a strong role in the drive of many nations to build WCUs. The cases of Denmark and India both outline how rankings have become closely involved and interwoven into national policy discourses. If the ranking instrument in this way has moved beyond a purely technical practice that aspires to measure performance to become a technology of government (Miller, and Rose, 1990), we have shown here how rankings and policy have both been 'in motion' and provide for a coordination with only limited control.

Recent studies have sought to investigate processes of international coordination to understand the actual 'interfaces' (Wright and Oerberg, 2011) between international policy processes, policy actors, and national situations. Likewise, new studies are now paying more attention to the differences among the players in the ranking industry and the diversity of methods employed by them in assessing policy 'progress' (Lim, 2015). Here we emphasize how policy mixes that appear similar across national contexts must be investigated with sensitivity to the particularity of their historical and political contexts and the differences in how they bring together actors and technologies to articulate diverse policy assemblages. A focus on ranking encounters strengthens the understanding of the tension between diversity and similarity in international coordination.

Rankings have been analyzed as drivers of reform in higher education and especially of the proliferation of the so called WCU model (Deem et al 2008). Rankings are becoming highly influential in government policy making and shaping it in certain ways (Hazelkorn, 2011; 2013). However the ways that rankings participate in the coordination of policies across national borders and the promotion of reform nationally cannot be assumed from their seeming consistency with reform processes. What we suggest is that we cannot assume that rankings are directly aligned with what institutional, national and international policy makers want. A better understanding 
of the convergence and disjuncture between developments in rankings and policy making may instead assist us in understanding better the multi-directional and multi-actor reality of international coordination in contemporary higher education policy.

The best known global rankings are organized as projects independent of universities, governments, and international policy actors. Their ascendance on to the global stage of higher education policy making has happened in parallel with growth in international student numbers, a heightened policy focus on internationalization and notably the development of the concept of the World Class University (Altbach and Balán, 2007). The different histories and organizational contexts behind the creation and operation of specific rankings are often left out of or only summarized in studies of university reform. Frameworks that treat rankings as businesses or as dynamic and responsive policy devices are rarely explored. Rankings are, as we have shown, 'active' ingredients and should be more carefully taken into account in the study of reform processes in which they are involved. The roles of rankers shift in reform processes but there are also changes in the very organization, tactics, and development of the rankers themselves. We suggest that rankings are a productive entry point to understanding both the multi-directional and multi-positional process of higher education reform. Further studies are needed to understand the way ranking and the business of ranking interact with, are productive within, or at odds with higher education reform.

\section{References}

Agarwal, P. (2013). Asia: Higher Education in India and Pakistan, Common Origin - Different Trajectories. In Schreuder, D. M. (Ed.) Universities for a New World: Making a Global Network in International Higher Education, 1913-2013. (pp. 254-283). New Delhi: Sage.

Altbach, P. (2016, February 18) India's passage might not be simple, but it can climb to elite tier. Times Higher Education. Retrieved from https://www.timeshighereducation.com/comment/philipaltbach-indias-passage-might-not-be-simple-but-it-can-climb-to-elite-tier

Altbach, P. G., \& Balán, J. (2007). World class worldwide: Transforming research universities in Asia and Latin America. Baltimore: JHU Press.

Baty, P. (2013). No Plans To Alter World Rankings: Times Higher Education. Interview with Smita Polite (2013 December 12). Edu-Leaders. Retrieved from: http://www.eduleaders.com/articles/37896/no-plans-to-alter-world-rankings-times-higher-education 
Berlingske Tidende. (2004). Hvad blev der af eliten? Interview: Asger Aamund, Linda Nielsen og Søren Barlebo Rasmussen. Berlingske Tidende, 2. Sektion, Magasin p. 14 (2004, December 4)

British Council (India) (2013). National Policy Dialogue on University Rankings. Retrieved from https://www.britishcouncil.in/programmes/higher-education/internationalising-highereducation/policy-dialogues/events/national-policy-dialogue

Collier, S.J. \& Ong, A. (2005) Global Assemblages, Anthropological Problems. In Collier, S.J. \& Ong, A. (Eds.) Global Assemblages: Technology, Politics, and Ethics as Anthropological Problems. Malden, MA: Blackwell.

Danish Government. (2006). Progress, Innovation, Cohesion. Strategy for Denmark in the Global Economy - Summary, May. Retrieved from http://www.stm.dk/multimedia/PROGRESS_INNOVATION_AND_COHESION.pdf

Danish Government. (2011). Internationalt konkurrencedygtige universiteter - Møde $i$ Vækstforum 21. januar 2011. Copenhagen: Danish Government - Vaekstforum. Retrieved from http://www.stm.dk/multimedia/internationalt_konkurrencedygtige_universiteter.pdf on 31/3/2016

Danish University and Property Agency. (2009). A10 DUPA: Trend and background note on the research area. In Collection of 'Enclosures for the 2009 evaluation'. Retrieved from http://ufm.dk/uddannelse-og-institutioner/videregaende-uddannelse/universiteter/omuniversiteterne/reformer-pa-universitetsomradet-1/universitetsevalueringen-i2009/baggrundsmateriale-1

Deem, R., Mok, K. H., \& Lucas, L. (2008). Transforming higher education in whose image? Exploring the concept of the 'world-class' university in Europe and Asia. Higher Education Policy, 21(1), 83-97.

Douglass, J.A. (2016). The New Flagship University: Changing the Paradigm from Global Ranking to National Relevancy. Palgrave MacMillan.

Elken, M., Hovdhaugen, E., \& Stensaker, B. (2016). Global rankings in the Nordic region: challenging the identity of research-intensive universities? Higher Education, 1-15.

Enserink, M. (2007). Who ranks the university rankers? Science, 3175841), 1026-1028.

European Commission. (2009). CREST OMC Working Group Report on: Mutual learning on approaches to improve the excellence of research in universities. Brussels: European Commission.

Frandsen, K. B. \& Lyall, T. W. (2012). Her er universiteternes placering på Leiden-ranglisten. Altinget.dk (2012, 5 December) Retrieved from http://www.altinget.dk/forskning/artikel/her-eruniversiteternes-placering-paa-leiden-ranglisten 
Indian Institute of Technology Delhi. (2014). Report of the External Peer Review Panel. September 4-6, 2014. New Delhi: IIT-Delhi.

Jessop, B. (2000). The state and the contradictions of the knowledge driven economy'. In Bryson, J. Daniels, P. Henry, N. \& Pollard, J.(Eds.) Knowledge, Space, Economy. London: Routledge.

Hazelkorn, E. (2011). Rankings and the reshaping of higher education: The battle for world-class excellence. Basingstoke: Palgrave Macmillan.

Hazelkorn, E. (2013) Reflections on a Decade of Global Rankings: What We've Learned and Outstanding Issues. Beitraege zur Hochschulforschung. 2/2013: 8-33

IANS. (2007). PM promises 30 world-class universities Hindustantimes.com (2007, June 22). Retrieved from http://www.hindustantimes.com/india/pm-promises-30-world-classuniversities/story-CQjJoLT0PjQzSzTPuaApTO.html Retrieved on 31/3/2016.

IIT Council. (2013). Minutes of the 47th meeting of the Council of IITs held on Friday, the 16th September, 2013. Retrieved from https://www.iitsystem.ac.in/Councildecisionsupload/bacb6099d151722a71c777f42e.pdf on 31/3/16

Kehm, B. M. (2014). Global University Rankings - Impacts and Unintended Side Effects. European Journal of Education. 49(1), 102-112.

Kyng, M. (2005). Er vi i verdensklasse? Ingeniøren p. 2 (2005, 4 February)

Lim, M.A. (2015). Global University Rankings: Determining the Distance Between Asia and 'Superpower Status' in Higher Education. In Bhandari, R. \& Lefebure, A. (Eds.), Asia: the Next Higher Education Superpower? New York: Institute for International Education.

Mahbubani, K. \& Chye, T.E. (2015). Is Asia the Next Higher Education Superpower? In Bhandari, R. \& Lefebure, A. (Eds.), Asia: the Next Higher Education Superpower? New York: Institute for International Education.

Miller, P., \& Rose, N. (1990). Governing economic life. Economy and society, 19(1), 1-31.

Ministry for Children, Education and Gender Equality (Denmark). (2010). Nordisk kvalitet i de videregående uddannelser. Ministry newsletter (2010, April 20). Retrieved from http://www.uvm.dk/Aktuelt/ /UVM-DK/Content/News/Udd/Videre/2010/Apr/100420-Nordiskkvalitet-i-de-videregaaende-uddannelser on 31/3/2016.

Ministry of Human Research Development. (India) (2011). Taking IITs to Excellence and Greater Relevance Report of Dr Anil Kakodkar Committee. Delhi: MHRD.

Ministry of Science, Technology and Innovation (Denmark). (2009a). The University Evaluation 2009 - Evaluation Report, Copenhagen: Ministry of Science, Technology and Innovation. 
Ministry of Science, Technology and Innovation (Denmark). (2009b). Forskningsbarometer 2009: Dansk forskning i internationalt perspektiv. Copenhagen: Ministry of Science, Technology and Innovation.

Naidoo, R., \& Jamieson, I. (2005). Empowering participants or corroding learning? Towards a research agenda on the impact of student consumerism in higher education. Journal of Education Policy, 20(3), 267-281.

Naidoo, R. \& Williams, J. (2015). The neoliberal regime in English higher education: charters, consumers and the erosion of the public good, Critical Studies in Education, 56(2), 208-223.

Naidoo, R., Shankar, A., \& Veer, E. (2011). The consumerist turn in higher education: Policy aspirations and outcomes. Journal of Marketing Management, 2711-12), 1142-1162.

NDTV. (2013). IIT rankings: what's money got to do with it? NDTV.Com (2013, November 23). Retrieved from http://www.ndtv.com/video/player/agenda/iit-rankings-what-s-money-got-to-dowith-it/291758

Ngok, K., \& Guo, W. (2008). The quest for world class universities in China: Critical reflections. Policy Futures in Education, 6(5), 545-557.

Prime Minister's Office (Denmark). (2010). DANMARK 2020 Viden > vækst > velstand > velfærd. Copenhagen: Prime Minister's Office.

Rajya Sabha (Indian Parliament). (2005). Ranking of Indian Universities. Debate item no. 685, 9/3/2005. Archive. Retrieved from http://rsdebate.nic.in/

Rajya Sabha (Indian Parliament). (2012). Oral Answers to Questions. Ranking and Standard of Indian Universities. 30/3/2012. Archive. Retrieved from http://rsdebate.nic.in/

Rajya Sabha (Indian Parliament). (2013). Ranking Indian Universities. Debate item no. 376, 9/12/2013. Archive. Retrieved from http://rsdebate.nic.in/

Rasmussen, H. M. (2006, 8 May). Sanders Mission Impossible. Mandag Morgen. Retrieved from www.mm.dk/sanders-mission-impossible.

Richter, L. (2016). Fyret uden at vide hvorfor. Information.dk (2016, March 23). Retrieved from https://www.information.dk/indland/2016/03/fyret-uden-vide-hvorfor

Salmi, J. (2009). The challenge of establishing world-class universities. Washington DC: World Bank Publications.

Shore, C., \& Wright, S. (1999). Audit culture and anthropology: neo-liberalism in British higher education. Journal of the Royal Anthropological Institute, 557-575. 
Steiner-Khamsi, G. (2014). Cross-national policy borrowing: understanding reception and translation, Asia Pacific Journal of Education, 34(2), 153-167.

Tang, U. (2009). Løkke: 10 mål Danmark skal nå inden 2020. Politiko (2016, March 31).

Retrieved from http://www.politiko.dk/nyheder/loekke-10-maal-danmark-skal-naa-inden-2020

Thakur, A. (2014) in Gohain, M.P. (2014, June 19). 10 Indian universities in Top 100 Asian university rankings. The Times of India. Retrieved from

http://timesofindia.indiatimes.com/home/education/news/10-Indian-universities-in-Top-100-Asianuniversity-rankings/articleshow/36786161.cms

Thakur, A. (2013) in Baty, P. (2013, June 5) 'India must embrace the internationalisation of higher education'. Times Higher Education. Retrieved from

https://www.timeshighereducation.com/world-university-rankings/news/india-embrace

Thakur, A. (2014, February 11) Remarks in 'India-specific Times Higher Education indicators soon'. Times of India. Retrieved from http://timesofindia.indiatimes.com/home/education/news/India-specific-Times-Higher-Educationindicators-soon/articleshow/30186409.cms

Tharoor, S. (2015). Why Harvard and Others Must be Allowed Into India. NDTV.com (2015, June 23). Retrieved from http://www.ndtv.com/opinion/why-harvard-and-others-must-be-allowed-intoindia-774410 on $31 / 3 / 2016$

Times of India, (2014, February 11) India-specific Times Higher Education indicators soon. Times of India. Retrieved from http://timesofindia.indiatimes.com/home/education/news/India-specificTimes-Higher-Education-indicators-soon/articleshow/30186409.cms

van Vught, F. (2009). Diversity and Differentiation in Higher Education. Mapping the Higher Education Landscape: Towards a European Classifi cation of Higher Education. F. van Vught. Dordrecht, Springer Netherlands: 1-16.

Wright, S. (2012). Ranking universities within a globalised world of competition states: to what purpose, and with what implications for students? In Andersen, H.L. \& Jacobsen, J.C. (Eds.) Uddannelseskvalitet i en globaliseret verden. (pp. 81-102). Frederiksberg: Samfundslitteratur.

Wright, S. \& Oerberg, J. W. ( 2011).The double shuffle of university reform - the OECD/Denmark policy interface. In Nyhagen, A. \& Halvorsen, T. (Eds.) Academic identities - academic challenges? American and European Experience of the Transformation of Higher Education and Research. (pp. 269-293). Newcastle upon Tyne: Cambridge Scholars Publishing.

Wright, S. \& Oerberg, J.W. (2016 Forthcoming). Universities in the competition state: lessons from Denmark. In Wright, S. \& Shore, C. (Eds.) Death of the Public University? Uncertain Futures for Higher Education in the Knowledge Economy, Chapter 3. Oxford: Berghahn. 
